\title{
Czytelnictwo w Bibliotece Raczyńskich w latach 2000-2009
}

\section{Wprowadzenie}

$\mathrm{N}$ kt nie rodzi się czytelnikiem, a w świat książki nie można wejść bez pomocy innych ludzi. Działania zmierzające do wychowania czytelnika powinny zostać zapoczątkowane $\mathrm{w}$ rodzinie ${ }^{1}$. To w niej poprzez przykład oraz głośne czytanie w dzieciach należy rozwijać zamiłowanie do książek. Jednak sytuacja materialna, problemy i pośpiech dnia codziennego sprawiają, że nie w każdej rodzinie kładzie się na to nacisk i dlatego rolę tę przejmują przedszkola, szkoły oraz biblioteki².

A jak przedstawiają się wyniki badań nad czytelnictwem? Otóż są one niepokojące. Według danych z roku 2008 tylko 38\% Polaków przeczytało przynajmniej jedną książkę drukowaną. Książka przegrywa z Internetem i telewizją, ale pocieszający może być fakt, że wzrasta zainteresowanie e-książkami i audiobookami. Wyniki badań Biblioteki Narodowej oraz

${ }^{1}$ M. Tajak, Rola rodziców w kształtowaniu czytelnictwa dzieci [on-line]. Pedagogiczna Biblioteka Wojewódzka w Krośnie [dostęp 15 grudnia 2010]. Dostępny w World Wide Web: http://www.krosno.pbw.org.pl/artykuly/rola\%20rodzicow.doc.

${ }^{2}$ vein2, Internet a czytelnictwo [on-line]. Sciaga.pl - edukacyjna baza wiedzy [dostęp 15 grudnia 2010]. Dostępny w World Wide Web: http://www.sciaga.pl/tekst/2645627-internet_a_czytelnictwo; U. Wesołowska, Czytelnictwo dzieci i młodzieży - rola książki $w$ życiu człowieka [on-line]. Towarzystwo Nauczycieli Bibliotekarzy Szkół Polskich. Oddział w Lublinie [dostęp 15 grudnia 2010]. Dostępny w World Wide Web: http://tnbsp_ od_lublin.republika.pl/podk/publikacje/wesolowska_czytelnictwo_dzieci_i_mlodziezy_ rola_ksiazki.htm. 
TNS OBOP wykazały, że coraz mniejsza liczba Polaków czyta i kupuje książki. Ci czytelnicy, którzy czytają, wolą książki wypożyczać niż kupować. W roku 2008 głównym źródłem książek dla czytelników były biblioteki - 40\% (w przeważającej większości publiczne), następnie księgozbiory znajomych oraz rodzinne, a dopiero na końcu zakupy ${ }^{3}$. Osoby, które sięgają po książki, to najczęściej ludzie z wykształceniem wyższym lub powyżej średniego ${ }^{4}$.

W celu stwierdzenia, jak kształtuje się czytelnictwo w Bibliotece Raczyńskich (dalej: BR), analizie porównawczej poddano jego stan w latach 2000-2009. Zbadano liczbę odwiedzin we wszystkich placówkach biblioteki, liczbę zarejestrowanych czytelników dorosłych, liczbę zarejestrowanych czytelników do lat 15 oraz liczbę zarejestrowanych czytelników ogółem.

\section{Wyniki badań}

W skład BR wchodzą następujące placówki: Biblioteka Główna, Centralna Wypożyczalnia, Muzeum Literackie Henryka Sienkiewicza, Pracownia-Muzeum Józefa Ignacego Kraszewskiego, Ośrodek Dokumentacji Wielkopolskiego Środowiska Literackiego, Mieszkanie-Pracownia Kazimiery Iłłakowiczówny, Izba Pamięci Jerzego Pertka, Oddział Biblioteki Raczyńskich w Sapowicach, 19 filii dla dorosłych, 12 dla dzieci i młodzieży oraz 18 łączonych (mających w swojej ofercie księgozbiory zarówno dla dorosłych, jak i dla dzieci i młodzieży) ${ }^{5}$.

W 2000 r. BR odwiedziło 1082773 czytelników ${ }^{6}$. W kolejnych latach, aż do roku 2003 włącznie, obserwowano wzrost liczby odwiedzin (od 1084948 w roku 2001 do 1169959 w roku 2003). Od roku 2004 do 2009 nastąpił postępujący regres liczby osób korzystających z zasobów biblio-

3 Tylko 38 proc. Polaków przeczytało przynajmniej jedną książkę w 2008 r. [on-line]. Polskie Radio Online [dostęp 15 grudnia 2010]. Dostępny w World Wide Web: http:// www.polskieradio.pl/nauka/artykul.aspx?id=92201.

${ }^{4}$ U. Wesołowska, dz. cyt.

${ }^{5}$ Stan na dzień 20.03.2010 r.

${ }^{6}$ Wyniki opracowano na podstawie sprawozdań z lat 2000-2009 z następujących placówek: Czytelni Ogólnej, Czytelni Czasopism, Centralnej Wypożyczalni, Działu Informacyjno-Bibliograficznego, Działu Zbiorów Specjalnych, filii dla dorosłych, filii dla dzieci i młodzieży, Muzeum H. Sienkiewicza, Muzeum J. I. Kraszewskiego, Domu Literatury, Izby Pamięci J. Pertka, Oddziału Dokumentów Życia Społecznego, Mieszkania-Pracowni K. Iłłakowiczówny. 
teki (rok 2004 - 1135476 osób; 2005 - 1065904 osoby; $2006^{7}$ - 992 989; 2007 - 920 318; 2008 - 865 631; 2009 - 852 216) (por. wykres 1).

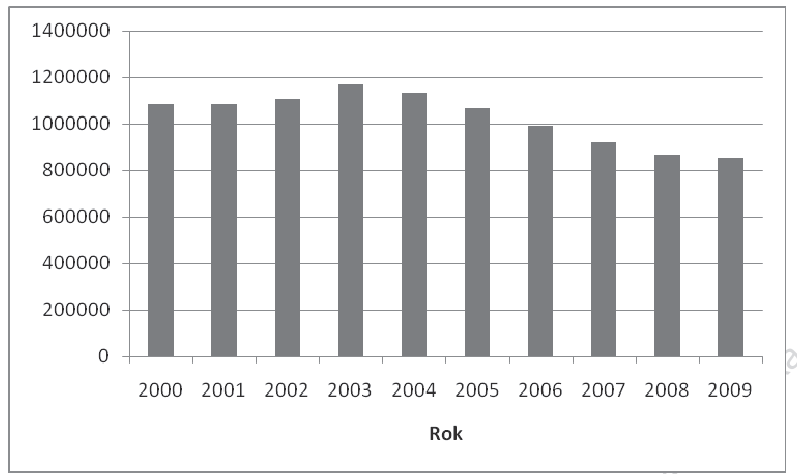

Wykres 1. Liczba odwiedzin we wszystkich placówkach Biblioteki Raczyńskich w latach 2000-2009

Źródło: Sprawozdania Biblioteki Raczyńskich z lat 2000-2009.

Odmienną tendencję, niż w przypadku liczby odwiedzin ogółem, stwierdzono w przypadku rejestracji osób dorosłych, jak również czytelników do lat 15 oraz ich ogólnej liczby (wykresy 2, 3, 4).

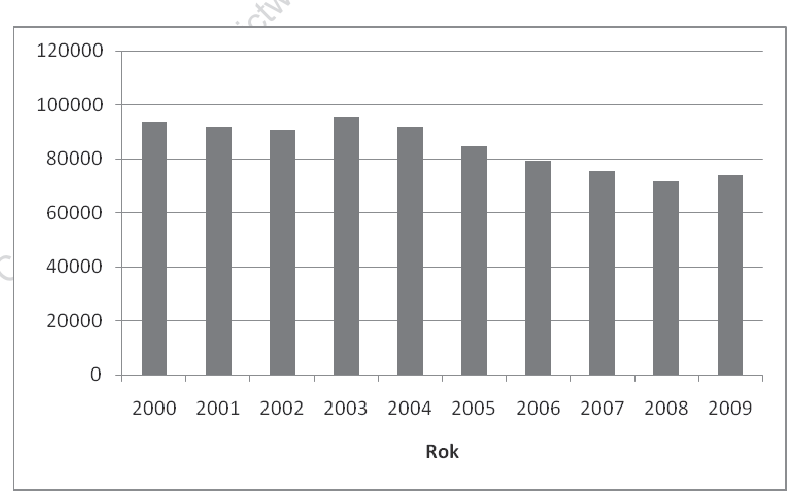

Wykres 2. Liczba zarejestrowanych czytelników dorosłych w latach 2000-2009 Źródło: Sprawozdania Biblioteki Raczyńskich z lat 2000-2009.

7 Dla porównania Bibliotekę Narodową w roku 2006 odwiedziło 176275 osób, w roku 2007 - 166 589, a w roku 2008 - 154216 osób. Podaję za: T. Makowski, Udostępnianie zbiorów Biblioteki Narodowej w 2008 r. [on-line]. Biblioteka Narodowa [dostęp 15 grudnia 2010]. Dostępny w World Wide Web: http://www.bn.org.pl/download/document/1241432549.pdf. 


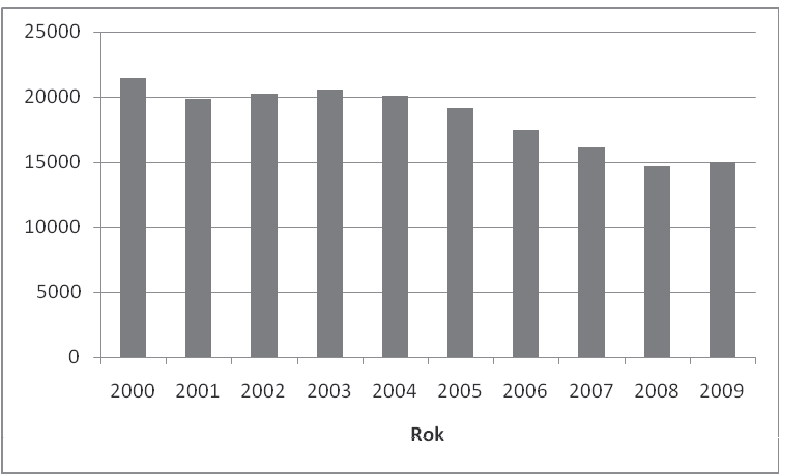

Wykres 3. Liczba zarejestrowanych czytelników do lat 15 w latach 2000-2009 Źródło: Sprawozdania Biblioteki Raczyńskich z lat 2000-2009.

Liczba czytelników dorosłych zarejestrowanych w roku 2000 wyniosła 93841 osób, a czytelników do lat 15 - 21426 osób. W roku 2001 zanotowano spadek zarejestrowanych czytelników z obu grup wiekowych (osoby dorosłe do 91 840, a osoby do lat 15 - 19 854). W roku 2002 nastąpił kolejny - w porównaniu z rokiem poprzednim - spadek zarejestrowanych osób dorosłych o 1022 osoby, przy równoczesnym wzroście liczby zapisów czytelników do 15 roku życia (z 19854 do 20223 osób). W roku $2003 \mathrm{w}$ obu grupach wzrosła liczba zapisujących się czytelników, odpowiednio o 4426 i 333 osoby. W latach 2004-2008 stwierdzono spadek liczby nowo rejestrowanych czytelników w obu grupach wiekowych. Rok 2009 przyniósł poprawę sytuacji - w przypadku czytelników dorosłych wzrost liczby rejestracji o 2361, a czytelników do lat 15 o 313, w stosunku do roku 2008.

Podobne tendencje jak w przypadku czytelników dorosłych stwierdzono przy analizie ogólnej liczby zarejestrowanych czytelników (wykres 4). W latach 2000-2002 nastąpił spadek rejestrujących się osób (ze $115267 \mathrm{w}$ roku 2000 do 111041 w roku 2002), a w roku 2003 wzrost o 4759 osób, w porównaniu z rokiem 2002. W kolejnych latach (2004-2008) liczba rejestrujących się osób ulegała obniżeniu, a w roku 2009 nastąpił jej wzrost o 2674 osoby (w porównaniu z rokiem poprzednim). 


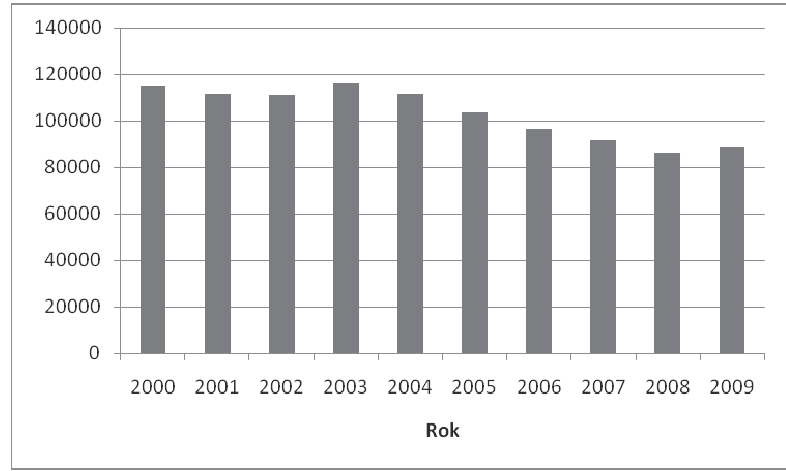

Wykres 4. Liczba zarejestrowanych czytelników (ogółem) w latach 2000-2009* Źródło: Sprawozdania Biblioteki Raczyńskich z lat 2000-2009.

* Statystycznie na 100 mieszkańców Poznania w roku 2000 przypadało 20 czytelników biblioteki, a w roku 2009 - 16.

\section{Wnioski i dyskusja}

W roku 2004 nastąpiła redukcja liczby placówek BR o sześć filii (w związku z czym ich liczba zmniejszyła się z 64 do 58), odnotowano także wówczas spadek czytelnictwa. Nie można jednoznacznie stwierdzić, że działanie to miało wpływ na mniejszą liczbę odwiedzin i rejestracji, ponieważ likwidacja placówek jest zgodna z koncepcją reorganizacji filii BR. Według niej sieć filii bibliotecznych, w której przeważają małe placówki, funkcjonujące często w nieodpowiednich warunkach lokalowych, nie będzie mogła w przyszłości zaspokoić rosnących potrzeb czytelniczych i informacyjnych. Z tego powodu BR będzie dążyć do stworzenia jednolitej sieci placówek o podobnym standardzie zbiorów, usług, lokali i wyposażenia, które będą rozlokowane w poszczególnych miejscach miasta w liczbie proporcjonalnej do liczby mieszkańców. Takich bibliotek na obszarze miasta Poznania powinno być $19^{8}$ zgodnie z kryterium: jedna biblioteka na 30 tys. mieszkańców.

Powstanie placówek o porównywalnych zasobach bibliotecznych i warunkach lokalowych stworzy możliwość zmodernizowania bibliotek publicznych zgodnie ze standardami europejskimi. Biblioteki nowego rodzaju mają cechować się lepszą jakością w porównaniu do zlikwidowanych.

${ }^{8}$ Stare Miasto - 5 placówek, Nowe Miasto - 5, Grunwald - 4, Jeżyce - 3, Wilda - 2. 
Będą także przystosowane do zmieniających się potrzeb czytelniczych, staną się bowiem nie tylko miejscami wypożyczania książek, ale także atrakcyjnymi centrami informacyjnymi i kulturalnymi dla społeczności lokalnych oraz pozostałych mieszkańców Poznania9.

Kolejnymi działaniami zmierzającymi do realizacji koncepcji reorganizacji filii była likwidacja filii nr 19 (rok 2006) oraz filii nr 40 (rok 2007). W roku 2009 liczba placówek wyniosła 56. Odnotowano wówczas wzrost rejestracji czytelników przy jednoczesnym nieznacznym spadku odwiedzin.

Działaniom likwidacyjnym towarzyszyła sukcesywna komputeryzacja pozostałych filii. Stan skomputeryzowania na dzień 31 grudnia $2009 \mathrm{r}$. był następujący: 32 filie były wyposażone w sprzęt komputerowy z dostępem do Internetu, z czego 28 oferowało dostęp do Internetu dla czytelników, 13 filii dysponowało sprzętem sieci PIAP, a 4 były w pełni skomputeryzowane (filie $\mathrm{nr}$ 2, 3, 14, 27 miały katalogi on-line, a udostępnianie odbywało się poprzez system Horizon). Jest to wyjście naprzeciw potrzebom społeczeństwa informacyjnego, o którego intensywnym rozwoju świadczy to, że obok spadku odwiedzin w tradycyjnej bibliotece odnotowano wyraźny wzrost wyświetleń na platformie Wielkopolskiej Biblioteki Cyfrowej. Od początku jej istnienia (2002 r.) do roku 2006 odnotowano 12450 wyświetleń zgromadzonych tam zasobów BR (w większości były to dokumenty życia społecznego). W roku 2008 zarejestrowano 8 tys. wyświetleń, a w roku 2009 - 7 tys. (w latach 2004-2009 ok. 40,6 tys. wyświetleń - nadal w większości dokumentów życia społecznego).

Uzyskane wyniki pozytywnie korelują z badaniami przeprowadzonymi w Bibliotece Narodowej. Wykazano w nich, że w ostatnich latach nastąpił spadek liczby użytkowników biblioteki korzystających z jej zbiorów w sposób tradycyjny (tj. w czytelniach), a wyraźnie wzrasta liczba użytkowników wirtualnych, korzystających z baz danych, katalogów internetowych i przede wszystkim z zasobów Cyfrowej Biblioteki Narodowej Polona ${ }^{10}$. W BR także zaobserwowano taką tendencję - coroczny wzrost wyświetleń na platformie Wielkopolskiej Biblioteki Cyfrowej.

Inne badanie przeprowadzone przez Bibliotekę Narodową wykazało, że w roku 2008 odnotowano najniższy wskaźnik czytelnictwa od czasu

${ }^{9}$ W. Spaleniak, Koncepcja reorganizacji filii Biblioteki Raczyńskich w Poznaniu. Biuletyn EBIB [on-line] 2003, nr 1 (41) [dostęp 15 grudnia 2010]. Dostępny w World Wide Web: http://ebib.oss.wroc.pl/2003/41/spaleniak.php.

10 T. Makowski, dz. cyt. 
systematycznie prowadzonych obserwacji na ten temat, tj. od 1992 r. Spadek przebiegał w sposób stopniowy: w latach 1994-2004 następowało zmniejszanie się intensywności czytania, a potem obniżyła się ogólna liczba czytelników (z 58\% w 2004 r. do 50\% w 2006 r. i 38\% w 2008 r.) ${ }^{11}$.

Ostatnia tendencja spadkowa dotknęła wszystkie kategorie społeczeństwa, z wyjątkiem mieszkańców największych, ponad 500-tysięcznych miast, gdzie wykazano, że odsetek czytelników nawet nieznacznie wzrósł (z 54\% w 2006 r. do 57\% w 2008 r.) ${ }^{12}$. Wyniki te potwierdziło badanie czytelnictwa w BR. W roku 2009 odnotowano wzrost nowo rejestrujących się osób. W przypadku odwiedzin liczba ta nie była już jednak aż tak duża.

Trudno jest jednoznacznie wskazać przyczyny spadku czytelnictwa w BR, która ze względu na bogate zbiory oraz organizowane imprezy kulturalno-oświatowe stanowi atrakcyjną dla czytelników placówkę. Zbiory biblioteki ze względu na ich przeznaczenie, charakter oraz sposób bibliotecznego opracowania są podzielone na trzy grupy: księgozbiór podstawowy wraz z Centralną Wypożyczalnią, zbiory specjalne oraz księgozbiory filii.

Łączna liczba woluminów znajdujących się w filiach bibliotecznych jest szacowana na około 950 tys. Filie obok książek czarnodrukowych oferują także filmoteki, książki nagrane na płytach CD, taśmach, compact-flash'ach oraz pisane alfabetem Braille’a. Atrakcyjność filii wzrasta również dzięki sukcesywnie wprowadzanemu dostępowi do Internetu.

Za przykład tego, jak interesujący i zróżnicowany wachlarz imprez BR oferuje dzieciom oraz dorosłym, niech posłuży rok 2009. W filiach dla dzieci zorganizowano aż 2728 imprez, były to: konkursy, lekcje biblioteczne, spotkania autorskie (z Łukaszem Wierzbickim, Wiesławem Drabikiem, Elizą Piotrowską, Janem Hyjkiem, Krzysztofem Smurą, Mariuszem Niemyckim, Krzysztofem Petkiem, Dariuszem Rekoszem), dyskusje nad książką, prelekcje, głośne czytanie, inscenizacje, wycieczki do biblioteki oraz poza bibliotekę, wyświetlanie filmów, projekcje bajek, warsztaty i zajęcia teatralne, zajęcia świetlicowe, gry, warsztaty i zajęcia plastyczne, pogadanki, imprezy czytelnicze, imprezy noworoczne, baliki, warsztaty

${ }^{11}$ K. Wolff, Biblioteka Narodowa analizuje stan czytelnictwa $w$ Polsce [on-line]. Mazowiecki System Informacji Bibliotecznej [dostęp 15 grudnia 2010]. Dostępny w World Wide Web: http://www.msib.pl/biblioteki/bp/bpgkozienice/imprezy/Strony/BibliotekaNarodowaanalizujestanczytelnictwawPolsce.aspx.

12 Tamże. 
i zajęcia muzyczne, „Przedszkole Moli Książkowych” oraz koło czytelnicze, a także zabawy integracyjne. Dużą popularnością wśród najmłodszych cieszyły się „Bajeczne Niedziele u Raczyńskich” (10 edycji) oraz „Akcja Zima” i „Lato z Książką”. Wielu uczestników skupiła też jesienna akcja dotowana przez Ministerstwo Kultury i Dziedzictwa Narodowego „Jesień Detektywów". W jej ramach przeprowadzono warsztaty specjalnie przygotowane pod kątem literatury detektywistycznej (zabawy fabularyzowane, zagadki, rebusy, konkursy, gry, łamigłówki literackie) oraz spotkania z ciekawymi formami plastycznymi zaproponowanymi przez siedmiu artystów plastyków. Oprócz tego wykonano 839 wystawek, plansz, haseł, plakatów i gazetek, co daje łącznie 3567 przykładów atrakcyjnych działań mających zachęcić młodego czytelnika do korzystania z biblioteki.

Również $\mathrm{w}$ filiach dla dorosłych zadbano o inne atrakcje niż tylko wypożyczanie książek. Zorganizowano spotkania autorskie (z Pawłem Andersem i Krzysztofem Styszyńskim), odbywały się zebrania Wielkopolskiego Towarzystwa Przyjaciół Książki, przeprowadzono akcję uwalniania książek (ang. Bookcrossing), zorganizowano (sfinansowane przez radę osiedla) zajęcia literackie dla dzieci i młodzieży oraz dla dorosłych, odbyła się sesja zdjęciowa studentki Akademii Sztuk Pięknych „Autoportret”, jedna z filii wzięła udział w akcji Gra Miejska „Klucz do Poznania”, w filii dla czytelników niewidomych przeprowadzono 19 lekcji Braille’a, pokazy sprzętu rehabilitacyjnego, zebrania klubu turystycznego „Razem na szlaku”, 31 lekcji komputerowych oraz 25 lekcji języka angielskiego.

Poza tym w ramach działalności upowszechnieniowej biblioteka była organizatorem trzech edycji konkursu literackiego „Poznański Przegląd Nowości Wydawniczych”, przeprowadziła coroczny „Konkurs im. J. Łukaszewicza" (nagroda honorowa za najlepszą książkę wydaną o Poznaniu w roku poprzednim), „Konkurs im. Arkadego Fiedlera o Nagrodę Bursztynowego Motyla" (jedyny taki w Polsce, podczas którego autorzy są nagradzani za najlepszą książkę o tematyce podróżniczej danego roku - konkurs jest finansowany przez Marszałka Województwa Wielkopolskiego).

W gmachu głównym biblioteki oraz w jej oddziałach (muzeach i pracowniach) zaprezentowano 23 wystawy, które swą tematyką obejmowały zarówno nowości, jak i zabytki literatury, malarstwo oraz rzeźbę. Inne nawiązywały do działań podjętych przez miasto (Biuro Programu „Trakt Królewsko-Cesarski”). W ramach tej współpracy zorganizowano wystawę prac studentów Wydziału Architektury Politechniki Poznańskiej „Plastyczne wizje Traktu Królewsko-Cesarskiego", czteropoziomowy konkurs 
plastyczny dla dzieci i młodzieży pod hasłem „Poznaj Raczyńskich”, pogadanki, warsztaty oraz lekcje biblioteczne uzupełnione pokazami multimedialnymi. We wrześniu odbył się „IV Weekend z Historią na Trakcie Królewsko-Cesarskim", w ramach którego na placu Wolności była prezentowana obszerna, wielkoformatowa wystawa plenerowa „Poznaj Raczyńskich", odbyła się konferencja naukowa, a także wystawy i warsztaty w oddziałach muzealnych biblioteki.

W maju zorganizowano piątą edycję Tygodnia Bibliotek pod hasłem „Biblioteka to plus”, w ramach której razem ze Stowarzyszeniem Bibliotekarzy Polskich czytelnikom zaproponowano m.in. „Wieczór w Bibliotece Raczyńskich", prezentację filmu o mistrzu introligatorskim Ryszardzie Ziembie, wykład Przemysława Wojciechowskiego „Problemy konserwacji materiałów archiwalnych”, warsztaty dla dzieci. Placówki muzealne BR przygotowały specjalny program na „Noc Muzeów” (16/17 maja). Tej samej nocy BR udostępniła swój gmach na specjalny pokaz multimedialny - video mapping, którego organizatorami były Poznańska Galeria Nowa i Stowarzyszenie Twórcze Nowa Nowa. Animacja komputerowa była poświęcona architekturze Biblioteki Raczyńskich.

Bardzo ważnym wydarzeniem był jubileusz 180-lecia BR, który obchodzono 5 maja 2010 r. Z tej okazji zorganizowano uroczystość jubileuszową dla pracowników oraz gości ze środowiska kultury i nauki.

Dużą popularnością cieszyła się także, zainicjowana w 2006 r. i odbywająca się dwa razy w roku, impreza kulturalna „Spotkanie z Arcydziełem", podczas której są prezentowane najcenniejsze zabytki z zasobów BR (sponsorem imprezy był bank PKO BP). Ponadto w ramach promocji biblioteki nakładem Wydawnictwa Miejskiego (dzięki wsparciu finansowemu Kompanii Piwowarskiej SA) ukazał się jubileuszowy informator o działalności BR, uwzględniający historię jej powstania, strukturę oraz bogatą działalność kulturalno-oświatową.

Biblioteka współpracowała również z lokalnymi środowiskami, jak rada osiedla - kółko recytatorskie „Słowo Twórcze”, ze szkołami podstawowymi (udostępnianie wystaw), wyższymi (organizacja wystaw, wieczorów autorskich, tematycznych), ośrodkami sztuki dla dzieci (konkursy, warsztaty), stowarzyszeniami literackimi (wieczory autorskie), Radiem Merkury (wspólna organizacja konkursu o bibliotece i jej fundatorze), a także środowiskami spoza Poznania. Z Polskim Teatrem Tańca - Baletem Poznańskim zorganizowano „Wieczorne przyjaciół i współpracowników wspominanie Conrada Drzewieckiego", podczas którego oprócz 
wysłuchania lub wymiany wspomnień o artyście można było obejrzeć filmowe fragmenty jego baletów. Należy podkreślić, że pracę kulturalną biblioteki wspomagają sponsorzy, doceniający jej wagę: Kompania Piwowarska SA i bank PKO BP.

Poza wymienioną działalnością kulturalną dwa duże projekty zyskały dofinansowanie z Wydziału Kultury i Sztuki w ramach starań Poznania o tytuł Europejskiej Stolicy Kultury 2016: jubileuszowa wystawa „Uratowane skarby piśmiennictwa polskiego i europejskiego" oraz cykl imprez i koncertów poświęconych Jackowi Kaczmarskiemu „A mury runęły..., realizowany przez Osiedlowy Dom Kultury „Pod Lipami”.

Wychodząc z tak szeroką ofertą imprez, BR ma na celu utrzymanie stałych oraz pozyskanie nowych czytelników. Szczególnie dzieciom i młodzieży chce jawić się jako atrakcyjne miejsce, w którym zawsze coś się dzieje. Spotkania z autorami książek, głośne czytanie przez znane osoby oraz inne zajęcia mają na celu w dyskretny sposób ukazać, że książki i czytanie są równie atrakcyjne jak popularne media, a korzyści, jakie się z nich czerpie - bezcenne. Wyrobienie w dzieciach skojarzenia: czytanie równa się przyjemność sprawi, że nie będą one spędzać czasu tylko przy komputerze, w Internecie czy przy telewizji.

Także imprezy oferowane czytelnikom dorosłym mają ten sam cel, poza tym dzieci, obserwując rodziców chodzących do biblioteki, będą w przyszłości ich naśladować.

Na koniec warto zadać sobie pytanie, czy nowe media będą w stanie w przyszłości na stałe zająć miejsce książek? Zdaniem Mieczysława Muraszkiewicza - nie. Według niego książka jako przedmiot niemal magiczny znajduje się w centrum ludzkiej kultury i tej formie ludzkiej ekspresji i komunikacji, które ona ucieleśnia, nowe technologie nie zagrażają. Co więcej, nowe technologie są w stanie ją wzmocnić i być może nawet doprowadzą do wyłonienia się nowego rodzaju sztuki. Myśl i wyobraźnia człowieka istnieją od zawsze, niezależnie od jakiejkolwiek technologii, i dlatego książka, która jest wytworem ludzkich myśli, będzie mu towarzyszyła po kres jego dni ${ }^{13}$.

${ }^{13}$ M. Muraszkiewicz, Jeszcze książka nie zginęła póki my żyjemy [on-line]. Institute for Computer and Information Engineering [dostęp 15 grudnia 2010]. Dostępny w World Wide Web: http://www.icie.com.pl/ARCHIVE/bibliomania.doc. 


\section{Reading statistics in Raczyński Library in 2000-2009 \\ Abstract}

The article shows reading statistics in Raczyński Library in 2000-2009. The number of visits to all library branches was recorded as well as numbers of registered readers: adults, below 15 years old and the total number of readers. It was shown that the number of visits to all Raczyński Library branches increased in 2000-2003, then decreased till 2009. As far as registration was concerned, after decreasing tendencies in 2003-2009, in the next year (2009) a growing tendency in registration was recorded. 